Jurnal Ilmu-Ilmu Peternakan 25 (3): 59 - 68

ISSN: 0852-3681

E-ISSN: 2443-0765

CFakultas Peternakan UB, http://jiip.ub.ac.id/

\title{
Total leukosit dan diferensial leukosit darah ayam broiler akibat penggunaan tepung onggok fermentasi rhizopus oryzae pada ransum
}

\author{
Dian Purnomo, Sugiharto dan Isroli \\ Fakultas Peternakan dan Pertanian Universitas Diponegoro \\ dianpurnomo595@gmail.com
}

\begin{abstract}
The aim of the present study was to determine the effect of cassava pulp fermented with Rhizopus oryzae onthe total leucocyte and differential leucocyte and its influence on the health of broiler chickens. The study was conducted in July-September 2015. The material used was 275 DOC of broiler with average of initial weight $55 \mathrm{~g}$. Ration ingredient used were corn, rice bran, soybean meal, fish meal, poultry meat meal and fermented cassava pulp. The experiment used a completely randomized design (CRD) comprised of 5 treatments and 5 replications. Treatment ration consist of T0 (control ration), T1 (8\% cassava pulp without fermentation), T2 (8\% cassava pulp fermented with Rhizopus oryzae), T3 (16\% cassava pulp fermented with Rhizopus oryzae) and T4 (24\% cassava pulp fermented with Rhizopus oryzae). The result of the study showed that there was no influence among treatments $(\mathrm{P}>0,05)$ of the use of cassava pulp fermented with Rhizopus oryzae in ration to total leucocyte and differential leucocycte. It is concluded that cassava pulp fermented with Rhizopus oryzae in ration is potential to substitute the use of corn in ration without compromising the health and amount of total leucocyte and differential leucocyte.
\end{abstract}

Keywords: Rhizopus oryzae, leuycocyte, differential leucocyte, broiler

\section{PENDAHULUAN}

Kesehatan merupakan faktor yang sangat menentukan keberhasilan usaha peternakan ayam broiler. Ayam yang sehat akan dengan mudah mengkonversikan pakan yang dikonsumsi menjadi daging, karena energi yang diperoleh dari pakan dapat sepenuhnya digunakan untuk pertumbuhan. Salah satu metode yang digunakan untuk menilai status kesehatan ayam broilermelalui penilaian hematologi. Secara umum total leukosit dan diferensial leukosit dapat memberikan gambaran dan status kesehatan pada hewan (Sugiharto,
2014). Isroli dkk. (2009) menyatakan bahwa untuk mengetahui tingkat kekebalan tubuh dapat dilihat dari variabel darahberupa leukosit dan diferensial leukosit secara lengkap.

Leukosit merupakan sel yang berperan dalam sistem pertahanan tubuh yang sangat tanggap terhadap agen infeksi penyakit. Leukosit berfungsi melindungi tubuh terhadap berbagai penyakit dengan cara fagosit dan menghasilkan antibodi (Junguera, 1977). Diferensial leukosit merupakan kesatuan dari sel darah putih yang terdiri dari dua kelompok yaitu granulosit yang terdiri atas heterosinofil, eusinofil, dan basofil, 
dan kelompok agranulosit yang terdiri dari limfosit dan monosit (Cahyaningsih dkk., 2007). Tingkat kenaikan dan penurunan jumlah leukosit dalam sirkulasi menggambarkan ketanggapan sel darah putih dalam mencegah hadirnya agen penyakit dan peradangan (Nordenson, 2002). Faktor-faktor yang mempengaruhi jumlah leukosit dan diferensialnya antara lain kondisi lingkungan, umur dan kandungan nutrisi pakan. Diantara faktor-faktor tersebut, faktor nutrisi (protein) memiliki peran yang sangat penting dalam proses pembentukan leukosit karena protein merupakan salah satu komponen darah (Addas et al., 2012; Etim et al., 2014).

Rhizopus oryzae merupakan fungi yang memiliki potensi probiotik. Selain itu, fungi yang diisolasi dari gathot tersebut menunjukkan aktivitas antioksidan yang tinggi (Sugiharto et al., 2015). Lebih lanjut dijelaskan bahwa fermentasi menggunakan fungi tersebut juga dapat menurunkan kadar serat kasar dan meningkatkan protein bahan pakan. Berdasarkan hasil tersebut, fermentasi dengan menggunakan Rhizopus oryzae yang diisolasi dari gathot diharapkan tidak hanya dapat memperbaiki nilai mutu nutrisi onggok, namun juga diharapkan dapat berpengaruh positif terhadap tingkat kesehatan ayam yang tercermin dari total leukosit dan diferensial leukosit darah ayam broiler. Oleh karena itu, penelitian ini bertujuan untuk mengetahui pengaruh pemberian onggok yang difermentasi dengan Rhizopus oryzae terhadap total leukosit, diferensial leukosit, kestabilan kesehatan dan fisiologis ayam broiler.

\section{MATERI DAN METODE}

Penelitianini dilaksanakan pada bulan Juli-September 2015. Materi yang digunakan adalah Day Old Chick (DOC) ayam broiler berjumlah 275 ekor dengan bobot awal rata-rata $55 \mathrm{~g}$. Peralatan yang digunakan meliputi kandang, ransum, peralatan pakan dan minum, instansi listrik, timbangan, thermometer dan hygrometer, alat tulis dan peralatan penelitian lainnya. Prosedur penelitian yang dilakukan terdiri dari 3 tahap yaitu tahap persiapan, tahap pemeliharaan dan tahap pengambilan data.

\section{Tahap persiapan}

Tahap persiapan yang dilakukan meliputi pembuatan starter, fermentasi bahan pakan dan penyusunan ransum serta persiapan kandang. Starter diperoleh dengan cara isolasi dari fermentasi gathot. Jamur Rhizopus oryzae dibiakkan dengan media Potato Dextrose Agar (PDA). Inkubasi dilakukan pada suhu $37^{\circ} \mathrm{C}$ selama 3 hari. Inokulum jamur Rhizopus oryzaediambil dari PDA dalam keadaan steril menggunakan spatula. Inokulum dilarutkan dalam $200 \mathrm{ml}$ akuades dan selanjutnya ditambahkan dengan 200 gram onggok yang telah diautoklaf pada suhu $121^{\circ} \mathrm{C}$ selama 15 menit, dimasukkan ke kantong plastik dan dilakukan pengadukan secara menyeluruh dan diinkubasi pada suhu kamar selama 14 hari.

Tahap fermentasi bahan pakan dilakukan dengan cara $10 \mathrm{~kg}$ onggok kering dimasukkan kedalam kantong plastik dan diautoklaf pada suhu $121^{\circ} \mathrm{C}$ selama 15 menit dan kemudian dimasukkankedalam ember plastik sebagai tempat fermentasi. Fermentasi dimulai dengan merendam onggok dengan air steril dalam rasio $1: 1(1 \mathrm{~kg}$ onggok : 1 liter air). Onggok diinokulasi dengan $55 \mathrm{~g} / \mathrm{kg}$ starter $\left(\mathrm{ca} 4 \times 10^{10} \mathrm{cfu} / \mathrm{g}\right.$ ) dan $41 \mathrm{~g} / \mathrm{kg}$ urea dan kemudian dicampur. Campuran tersebut diinkubasi selama 14 hari dan diaduk setiap 2 hari sekali. Hasil fermentasi dikeringkan dibawah sinar matahari selama 2 hari. Sebelum digunakan untuk formulasi ransum, sampel dari ember fermentasi 
yang berbeda diperoleh dan dikumpulkan untuk dianalisis proksimat.

Tahap penyusunan ransum dilakukan dengan pemilihan bahan pakan yang meliputi tepung jagung, bekatul, bungkil kedelai, tepung ikan, PMM, onggok dan onggok fermentasi.

Penyusunan ransum dilakukan dengan menghitung kebutuhan nutrien ternak, menimbang bahan pakan sesuai komposisi, dan mencampur bahan pakan yang digunakan. Formulasi dan kandungan nutrien ransum dapat dilihat pada Tabel 1.

Tabel 1. Formulasi ransum dan kandungan nutrien pakan

\begin{tabular}{|c|c|c|c|c|c|}
\hline \multirow{2}{*}{ Bahan pakan } & T0 & $\mathrm{T} 1$ & $\mathrm{~T} 2$ & T3 & $\mathrm{T} 4$ \\
\hline & \multicolumn{5}{|c|}{ 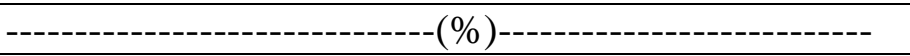 } \\
\hline Jagungkuning & 50,0 & 48,0 & 44,0 & 39,0 & 36,0 \\
\hline Bekatul & 18,0 & 10,0 & 19,0 & 17,5 & 13,0 \\
\hline Bungkilkedelai & 26,0 & 26,0 & 17,0 & 17,5 & 17,5 \\
\hline Tepungikan & 2,0 & 1,0 & 3,5 & 3,0 & 4,0 \\
\hline Poultry meat meal(PMM) & 4,0 & 7,0 & 8,5 & 7,0 & 5,5 \\
\hline Onggok & - & 8,0 & - & - & - \\
\hline Onggok + R. Oryzae & - & - & 8,0 & 16,0 & 24,0 \\
\hline \multicolumn{6}{|l|}{ Kandungan nutrien } \\
\hline $\mathrm{EM}(\mathrm{kkal} / \mathrm{kg})^{* *}$ & 2924,0 & 2925,0 & 2961,0 & 2943,0 & 2932,0 \\
\hline Protein kasar $(\%)^{*}$ & 22,5 & 22,7 & 22,9 & 23,8 & 24,3 \\
\hline Serat kasar (\%) & 9,3 & 8,9 & 8,9 & 9,0 & 11,8 \\
\hline Lemak kasar (\%) & 1,3 & 1,0 & 1,7 & 1,7 & 1,3 \\
\hline $\operatorname{Abu}(\%)$ & 9,2 & 7,5 & 11,6 & 11,2 & 10,8 \\
\hline Air $(\%)$ & 11,7 & 11,8 & 11,9 & 13,2 & 14,0 \\
\hline
\end{tabular}

Keterangan :

(*) Komposisi ransum yang ada pada tabel sebagian telah terpublikasi di jurnal Livestock Research (Sugiharto et al., 2016).

(**) Nilai Energi Metabolis (EM) dihitung berdasarkan rumus Balton (Siswohardjono, 1982).

$\mathrm{EM}: 40,81 \times(0,87(\mathrm{PK}+(2,25 \times \mathrm{LK})+\mathrm{BETN})+2,5$

\section{Tahap pemeliharaan}

Tahap pemeliharaan dimulai dengan tahap chick indimanaDOC yang akan dipelihara ditimbang bobot badannya lalu diberi air minum berupa larutan isotonik (pocary sweat) yang bertujuan untuk mengganti cairan yang hilang selama perjalanan. Perlakuan pakan dilakukan mulai hari pertama dimana pakan diberikan secara ad libitum sesuai kebutuhan ternak. Pemberian pakan dan air minum dilakukan sekali/hari dengan frekuensi pemberian 2-4 kali. Penimbangan pakan yang diberikan dilakukan setiap
hari.Selain itu juga dilakukan penimbangan sisa pakan untuk mengetahui konsumsi ternak setiap hari serta penimbangan bobot badan ternak yang dilakukan pada hari ke-7, 14, 21, 28, dan 35 .

\section{Tahap pengambilan data}

Tahap pengambilan data dilakukan pada hari ke 35 dengan pemuasaan ternak selama 3 jam sebelum pengambilan darah. Metode pengambilan darah dilakukan dengan memilih 1 sampel secara acak pada setiap unit flock. Pengambilan darah 
dilakukan melalui pembuluh vena brachialis menggunakan spuit (disposible syringe). Darah yang diambil minimal sebanyak $1 \mathrm{ml}$ dan ditampung pada tabung EDTA yang mengandung antikoagulan.Tabung dikocok secara perlahan dan disimpan pada suhu rendah $\left(18^{\circ} \mathrm{C}\right)$ untuk menghindari lisis atau penggumpalan darah. Darah yang akan diuji di lab disimpan pada cooler box.

Penghitungan jumlah leukosit ditentukan dengan metode ruang Burker. Penghitungan diferensial leukosit darah ayam broiler ditentukan dengan penghitungan preparat apus menggunakan mikroskop cahaya dengan lensa perendaman. Teknik coverslip diterapkan saat menyiapkan smear darah.

\section{Rancangan penelitian}

Rancangan percobaan yaitu Rancangan Acak Lengkap (RAL) yang teriri dari 5 perlakuan yaitu T0, T1, T2,T3, T4 dan 5 ulangan. Setiap ulangan terdiri dari 11 ekor ayam. Rancangan percobaan yang digunakan yaitu

- T0 : Ransum kontrol tanpa onggok

- T1 : Ransum menggunakan onggok $8 \%$

- $\mathrm{T} 2$ : Ransum menggunakan onggok fermentasi $R$. oryzae $8 \%$

- T3 : Ransum menggunakan onggok fermentasi $R$. oryzae $16 \%$

- T4 : Ransum menggunakan onggok fermentasi $R$. oryzae $24 \%$

Data diuji menggunakan analisis ragam.Apabila hasil menunjukkan pengaruh nyata maka dilanjutkan dengan ujijarak ganda Duncan.

\section{HASIL DAN PEMBAHASAN}

Rerata total leukosit dan diferensial leukosit darah ayam broiler dengan penggunaan tepung onggok yang difermentasi dengan fungi Rhizopus oryzae pada ransum disajikan pada Tabel 2.

Tabel 2. Rataan total leukosit, heterofil, eosinofil, limfosit dan monisit ayam broiler umur 35 hari akibat penggunaan tepung onggok fermentasi fungi Rhizopus oryzae pada ransum

\begin{tabular}{lccccc}
\hline \multirow{2}{*}{ Variabel } & \multicolumn{5}{c}{ Perlakuan } \\
\cline { 2 - 6 } & T0 & T1 & T2 & T3 & T4 \\
\hline Leukosit $\left(\mathrm{x} \mathrm{10}^{3} / \mathrm{ml}\right)$ & 20,12 & 16,65 & 16,03 & 16,48 & 28,13 \\
Heterofil (\%) & 30,40 & 31,60 & 37,33 & 52,00 & 40,00 \\
Eosinofil (\%) & 26,00 & 24,40 & 21,33 & 20,00 & 27,20 \\
Limfosit (\%) & 39,20 & 37,60 & 32,80 & 25,60 & 31,00 \\
Monosit (\%) & 10,40 & 9,00 & 6,40 & 12,00 & 9,00 \\
\hline
\end{tabular}

$\overline{\text { Keterangan : Rataan total leukosit, heterofil, eosinofil, limfosit dan monosit menunjukkan }}$ tidak ada perbedaan nyata $(\mathrm{P}>0,05)$.

\section{Total leukosit darah ayam broiler}

Tabel 2 menunjukkan bahwa penggunaan tepung onggok yang difermentasi dengan fungi Rhizopus oryzae dalam ransum tidak berpengaruh nyata $(\mathrm{P}>0,05)$ terhadap total leukosit darah ayam broiler pada umur 35 hari. Total leukosit pada penelitian ini berkisar 16,03-28,13 × 103/ml, dimana hasil tersebut berada pada angka yang normal. Smith dan Mangkoewidjojo (1998) dan Swenson (1984) melaporkan bahwa secara normal jumlah leukosit pada darah ayam broiler berada pada kisaran antara 6-40 × 103 $/ \mathrm{ml}$.

Leukosit merupakan unit aktif dari sel darah yang berperan dalam sistem pertahanan tubuh dari serangan penyakit yang dapat digunakan sebagai indikator tingkat kesehatan dan status 
fisiologis ayam broiler. Hartoyo dkk. (2015) menyatakan bahwa fungsi dari leukosit yaitu menjaga tubuh dari patogen dengan cara fagositosis dan menghasilkan antibodi. Faktor-faktor yang menentukan jumlah leukosit antara lain aktivitas biologis, kondisi lingkungan, umur dan pakan. Hal ini sesuai dengan pendapat Guyton dan Hall (1997) yang menyatakan bahwa total leukosit yang menggambarkan tingkat kesehatan dipengaruhi oleh beberapa faktor baik internal yang meliputi jenis kelamin, umur, penyakit dan hormon maupun faktor eksternal seperti keadaan lingkungan, aktivitas ternak, stress dan pakan yang diberikan.

Berdasarkan data pada Tabel 2 terlihat bahwa terjadi penurunan jumlah leukosit pada T1, T2 dan T3 dibandingkan T1 dan meningkat pada T4 (pemberian taraf $24 \%$ ) tetapi penurunan dan peningkatan jumlah leukosit masih berada pada kisaran normal. Peningkatan dan penurunan leukosit dalam darah merupakan mekanisme respon tubuh terhadap patogen yang menyerang. Tingginya produksi leukosit belum dapat diasumsikan bahwa ternak tersebut dalam keadaan sakit. Peningkatan jumlah leukosit menggambarkan adanya respon secara humoral dan seluler dalam melawan agen patogen penyebab penyakit dalam tubuh. Moyes dan Schute (2008) dan Soeharsono dkk. (2010) menyatakan bahwa kesehatan fisik ternak dapat diukur melalui jumlah leukosit yang dihasilkan, dimana peningkatan jumlah leukosit menandakan adanya peningkatan kemampuan pertahanan tubuh. Sedangkan penurunan jumlah leukosit juga dapat diasumsikan bahwa tidak adanya infeksi atau gangguan bakteri patogen yang menyerang tubuh. Oleh karena itu, perlu diketahui secara keseluruhan jumlah leukosit dan diferensial leukosit untuk mengetahui kondisi kesehatan ternak secara pasti. Akhirnya, berdasarkan data yang diperoleh dari penelitian ini dapat diasumsikan bahwa pemberian onggok fermentasi dalam ransum mampu menjaga tingkat kestabilan kesehatan ayam broiler.

\section{Persentase diferensial leukosit}

Berdasarkan hasil penelitian pada Tabel 2, persentase heterofil pada darah ayam broiler berumur 35 hari dengan penggunaan tepung onggok fermentasi Rhizopus oryzae dalam ransum tidak berbeda nyata antar perlakuan. Persentase heterofil pada darah ayam broiler berdasarkan hasil penelitian berada pada kisaran 30,40$52,00 \%$ dimana hasil tersebut tergolong normal. Hendro dkk. (2013) menyatakan bahwa persentase heterofil yang normal pada darah ayam broiler berada pada kisaran 20-40\%.

Heterofil adalah bagian dari leukosit yang termasuk kedalam kelompok granulosit dan berada pada garis depan (first line) yang berfungsi sebagai pertahanan awal terhadap penyakit yang dapat mengakibatkan infeksi atau peradangan. Baratawidjaja dan Rengganis (2012) menambahkan bahwa sistem kerja heterofil yaitu menghancurkan patogen melalui jalur oksigen independen (lisozom, enzim proteolitik dan protein kationik) dan oksigen dependen. He et al. (2005) dan Redmond et al. (2011) melaporkan bahwa heterofil mengandung zat antimikroba yang berhubungan dengan resistensi penyakit pada tubuh dan dipengaruhi oleh kontrol genetik dari ternak tersebut. Faktor-faktor yang menentukan tinggi rendahnya heterofil antara lain kondisi lingkungan, tingkat stress pada ternak, genetik dan kecukupan nutrien pakan (Puvadolpirod and Thaxton, 2000). 
Hasil penelitian menunjukkan bahwa persentase eosinofil pada darah ayam broiler berumur 35 hari dengan penggunaan tepung onggok yang difermentasi dengan Rhizopus oryzae dalam ransum memberikan hasil tidak berbeda nyata antar perlakuan. Persentase eosinofil yang diperoleh berada pada kisaran 20-27,20\% dimana persentase tersebut melebihi kisaran batas normal. Jain (1986) menyatakan bahwa pada kisaran normal jumlah eosinofil 2-8\% dari jumlah sel darah putih dan dapat bertahan hidup 3-5 hari. Tingginya persentase eosinofil dalam darah belum dapat diasumsikan bahwa ayam tersebut berada pada kondisi sakit. Tingginya produksi eosinofil juga dapat menunjukkan berfungsinya sistem pertahanan tubuh dalam menghadapi agen penyakit.

Eosinofil merupakan bagian dari diferensial leukosit yang dibentuk dalam sumsum tulang belakang yang berfungsi sebagai respon parasitik, peradangan dan alergi. Lokapirnasari dan Yulianto (2014) menyatakan bahwa eosinofil memiliki dua fungsi utama yaitu mampu menyerang dan menghancurkan bakteri patogen serta mampu menghasilkan enzim yang dapat menetralkan faktor radang. Dalam mencegah masuknya infeksi pada tubuh, eosinofil bekerja dengan fungsi kimiawi secara enzimatik. Hal ini sesuai pendapat Moyes danSchute(2008) serta Isroli dkk. (2009) yang menyatakan bahwa eosinofil melakukan fungsi imun melawan mikroorganisme dengan cara sebagaimana fungsi kimiawi yakni secara enzimatik. Faktor- faktor peningkatan eosinofil dapat terjadi karena hipersensitivitas misalnya karena parasit dan alergi yang diakibatkan faktor lingkungan yang bising dan berdebu (Dharmawan, 2002) dimana kedua kondisi tersebut terjadi pada saat penelitian dilaksanakan.
Hasil penelitian juga menemukan bahwa penggunaan tepung onggok yang difermentasi dengan Rhizopus oryzae dalam ransum tidak berpengaruh nyata $(\mathrm{P}>0,05)$ terhadap persentase limfosit darah ayam broiler umur 35 hari. Persentase limfosit yang diperoleh berada pada kisaran 25,6-39,2\% dan hasil tersebut tergolong normal. Hal ini sesuai pendapat Smith dan Mangkoewidjojo (1988)serta Guyton dan Hall (1997) yang menyatakan bahwa secara normal jumlah limfosit berada pada kisaran 24-84\%. Limfosit merupakan sel darah putih yang termasuk kedalam kelompok agranulosit. Salasia dan Hariono (2010) menyatakan bahwa limfosit bertugas merespon adanya antigen dan stress dengan meningkatkan sirkulasi antibodi dalam pengembangan sistem imun. Siegel (1995), Puvadolpirod and Thaxton (2000)melaporkan bahwa faktor-faktor terbesar yang mempengaruhi jumlah limfosit yaitu cekaman panas atau lingkungan dan stress, karena cekaman panas mengakibatkan berkurangnya bobot organ limfoid timus dan bursa fabrisius yang berdampak pada penurunan jumlah limfosit.

Hasil penelitian juga membuktikan bahwa penggunaan tepung onggok yang difermentasi dengan Rhizopus oryzaedalam ransum tidak memberikan pengaruh nyata terhadap persentase monosit pada darah ayam broiler berumur 35 hari. Persentase monosit yang diperoleh pada penelitian ini berkisar 6,4-12\%, dimana hasil tersebut tergolong normal. Hal ini sesuai pendapat sesuai pendapat Eroschenko (2008) yang menyatakan bahwa batasan normal nilai monosit pada darah ayam broiler yaitu 3-10\%. Monosit merupakan diferensial sel darah putih yang termasuk kedalam kelompok agranulosit yang dibentuk di sumsum tulang dan mengalami pematangan ketika masuk 
kedalam sirkulasi sehingga menjadi makrofag dan masuk ke jaringan. Frandson et al.(2009) mengatakan bahwa monosit mampu memfagositosis 100 sel bakteri patogen dan menjadi sistem pengatur ketika terjadi peradangan dan merespon kekebalan. Monosit dimobilisasi bersama dengan heterofil sehingga disebut sebagai pertahanan kedua terhadap peradangan.

Pemberian pakan onggok yang difermentasi dengan fungi Rhizopus oryzae bertujuan untuk mengurangi proporsi jagung dalam ransum, mengingat semakin tingginya harga bahan pakan tersebut. Onggok yang difermentasi dengan fungi Rhizopus oryzae memiliki kandungan protein kasar 22,76-24,31\% dan energi metabolis 2925-2961 kkal/kg. Hasil analisis Laboratorium Ilmu Nutrisi dan PakanFakultas Peternakan dan Pertanian Universitas Diponegoro menunjukkan bahwa kandungan protein dan energi metabolis tersebut sama dengan protein dan energi metabolis pada jagung. Berdasarkan hasil yang diperoleh, penggunaan onggok yang difermentasi dengan fungi Rhizopus oryzae tidak mengurangi kecukupan nutrisi ayam broiler. Hal tersebut diindikasikan pada data performan ayam broiler yang tidak berbeda nyata antar perlakuan. Lebih lanjut ditemukan bahwa jumlah leukosit dan diferensial leukosit juga tidak berbeda nyata antara ayam yang diberi pakan jagung dan ayam yang diberi pakan perlakuan.

Onggok yang difermentasi dengan Rhizopus oryzae diharapkan memiliki peran sebagai probiotik dan antioksidan sehingga baik bagi kesehatan ayam broiler. Hal tersebut didasari oleh fakta bahwa Rhizopus oryzae memiliki potensi probiotik dan antioksidan (Sugiharto et al., 2015 dan Sugiharto et al., 2016). Manin dkk. (2014) menyatakan bahwa pemberian probiotik pada unggas dapat memperbaiki penyerapan nutrisi dan meningkatkan kesehatan tubuh. Probiotik juga mampu meningkatkan kesehatan ternak dengan cara menyeimbangkan mikroflora dalam saluran pencernaan dan mengendalikan mikroba pathogen dalam saluran pencernaan jika dikosumsi dalam jumlah yang cukup (Budiansyah, 2004 dan Sugiharto, 2014). Widhyari dkk. (2009) dan Kabir et al. (2004) melaporkan bahwa pemberian probiotik dan antioksidan dalam gathot atau onggok mampu mempertahankan integritas membran penyusun dan meningkatkan aktivitas jaringan limfoid. Genus Rhizopus mampu meningkatkan kandungan protein dari bahan baku dan protein ini memiliki aktivitas fungsional dan aktivitas katalitik tertentu (Oliveira et al., 2010 dan Purwandari, 2014). Jamur dari genus ini juga mampu memecah senyawa komplek menjadi sederhana sehingga memudahkan proses pencernaan.

Selain sebagai probiotik, fungi Rhizopus oryzae juga berperan sebagai antioksidan untuk memperbaiki kekebalan tubuh (Sugiharto et al., 2016). Secara keseluruhan jumlah leukosit dan diferensial leukosit tergolong normal dan dapat diasumsikan bahwa ayam broiler tersebut berada pada kondisi yang sehat. Antioksidan dibutuhkan oleh tubuh untuk menangkal radikal bebas sebagai penyebab stress oksidatif. Istiani (2010) dan Schmidt et al. (2014) menyatakan bahwa antioksidan atau antiradikal dalam tubuh bekerja melawan stress oksidatif akibat ketidakseimbangan antara oksidan dan sistem pertahanan oksidan. Selain itu, fungi Rhizopus oryzae juga menghasilkan senyawa isoflavon yang berfungsi sebagai pertahanan tubuh. Hal ini sesuai dengan pendapat Pawiroharsono (2001) dan Nara et al. 
(2006) yang menyatakan bahwa fungi Rhizopus sp berpotensi menghasilkan senyawa isoflavon ketika proses fermentasi berfungsi sebagai pertahanan tubuh dari mikroba patogen.

Berdasarkan hasil diatas, dapat diasumsikan bahwa onggok yang difermentasi dengan fungi Rhizopus oryzae dapat berpotensi menggantikan proporsi jagung dalam ransum tanpa menggangu pembentukan sel darah putih dan diferensialnya.

\section{KESIMPULAN}

Berdasarkan hasil penelitian dapat disimpulkan bahwa penggunaan onggok yang difermentasi dengan fungi Rhizopus oryzae dalam ransum berpotensi sebagai probiotik dan mampu mempertahankan tingkat kestabilan kesehatan dan menjaga kondisi fisiologis ayam broiler.

\section{DAFTAR PUSTAKA}

Addass, P. A., David, I. Edward, A. Zira dan Midak. 2012. Effect of age, sex and management system on some haematological parameters of intensively and semi-intensively kept chicken in Mubi. Adamawa State, Nigeria. Iranian J. of App. Anim. Sci. 2 (3) : 277-282.

Baratawidjaja, K. G dan I. Rengganis. 2012. Imunologi dasar. Edisi IX. Badan Penerbit Fakultas Kedokteran Universitas Indonesia. Jakarta.

Budiansyah, A. 2004. Pemanfaatan probiotik dalam meningkatkan penampilan produksi ternak unggas. Program Pascasarjana Intitut Pertanian Bogor. Bogor. (Tesis).

Cahyaningsih, U., Malichatin. H dan Y. E. Hedianto. 2007. Diferensial leukosit pada ayam setelah diinfeksi Eimeria tanella dan pemberian serbuk kunyit (Curcuma domestica) dosis bertingkat. Prosiding Seminar Nasional Teknologi Peternakan dan Veteriner. Hal: 593-599.

Dharmawan, N. S. 2002. Pengantarpatologi klinik veteriner. Pelawa Sari.Denpasar.

Etim, N., E. Enyinihi, U. Akpabio dan Edem. 2014. Effects of nutrition on haemotology of rabbits : A review. J. European Sci. 10 (3): 413-423.

Eroschenko, V. P. 2008. Di Fiore's atlas of histology with functional correlations. Edisi Kesebelas. Lippincott Williams \& Wilkins, Philadelpia.

Frandson, R. D., W. L. Wike dan A. D. Fails. 2009.

Anatomyandphysiologyof farm animal. Edisi Ketujuh.WilleyBlackwell, Iowa.

Guyton, A. C.dan J. E. Hall.1997.Fisiologikedokteran.

EGC:Jakarta. (Diterjemahkan oleh Irawati, K. A. Tengadi dan A. Santoso).

Hartoyo, B., S. Suhermiyati, N. Iriyanti dan E. Susanti. 2015. Performan dan profil hematologis darah ayam broiler dengan suplementasi herbal (fermenherfit). Prosiding Seminar Nasional Teknologi dan Agribisnis Peternakan (Seri III): Pengembangan peternakan berbasis sumber daya lokal untuk menghadapi Masyarakat Ekonomi ASEAN (MEA). Fakultas Peternakan Universitas Jendral Soedirman, Purwokerto.

He, H., V. K. Lowry, P. M. Ferro dan M. H. Kogut. 2005. CpG oligodeoxynucleotide stimulated chicken heterophil degranulation is serum cofactor and cell surface 
receptor dependent. Dev Comp Immunol. 29 : 255-264.

Hendro, L. Adriani dan D. Latipudin. 2013. Pengaruh pemberian lengkuas (Alpinia galanga) terhadap kadar neutrofil dan limfosit ayam broiler. Prosiding Seminar Nasional Peternakan. Hal: 531-536.

Isroli, S. Susanti, E. Widiastuti, T. Yudiarti dan Sugiharto. 2009. Observasi beberapa variabel hematologis ayam Kedu pada pemeliharaan intensif. Prosiding Seminar Nasional Kebangkitan Peternakan. Hal: 548-557.

Istiani, Y. 2010. Karakteristik senyawa bioaktif isoflavon dan uji aktivitas antioksidan dari ekstrak etanol tempe berbahan Koro Pedang (Canavalio ensiformis). Program Studi Biosains. Program Pasca Sarjana Universitas Sebelas Maret. Surakarta. (Tesis).

Jain, N. C. 1986. Schalm's veteriner hematology. Edisi Keempat. Philadelphia. Lea \& Febiger.

Junguera, L. C. 1977. Basic histology. Edisi Kedelapan. McGraw-Hill, New York.

Kabir, S. M. L., M. M. Rahman, M. B. Rahman dan S. U. Ahmed. 2004. The dynamic of probiotic on growth performance and immune respone in broiler. Int. J. of Poult. Sci. 3 (5) : 361-364.

Lokaspirnasari, W. R dan A. B. Yulianto. 2014. Gambaran sel eosinofil, monosit, dan basofil setelah pemberian spirulina pada ayam yang diinfeksi virus flu burung. J. Vet. 15 (4) : 499-505.

Manin, F., E. Hendalia, Yatno dan P. Rahayu. 2014. Dampak pemberian probiotik FM terhadap status kesehatan ternak
Itik Kerinci. J. Ilmu Ternak. 1 (2): 7-11.

Moyes, C.D. and P. M. Schulte. 2008. Principles of animal physiology. Edisi Kedua. Perarson International Edition, NewYork

Nara, K., T. Miyoshi, T. Honma dan H. Koga. 2006. Antioxidante activity of bound-form phenolics in potato pell. Bioscience, Biotechnology and Biochemistry 70 : 1489-1491.

Nordenson, N. J. 2002. White Blood Cell Count and Differential. http://www. Lifesteps .com/gm. Atoz/ency

/white_blood_cell_count_and_di fferential. jsp. [April 2015].

Oliveira, M. S., L. Kupski, Feddern, E. Cipolatti, B. Furlong dan S. Soares. 2010. Physico-chemical characterization of fermented rice bran biomas. J. Food Reseach 8 : 236-269.

Purwandari, U., G. R. Tristiana dan D. Hidayati. 2014. Gluten-free noodle made from gathotan flour: antioxidant activity and effect of consumption on blood glucose level. J. International Food Research Journal 21 (4): 16291634.

Pawiroharsono, S. 2001. Prospek dan manfaat isoflavon untuk kesehatan. Direktorat Teknologi Bioindustri. Badan Pengkajian dan Penerapan Teknologi.

Puvadolpirod and Thaxton. 2000. Model of physiological stress in chicken. Edisi Kelima. Quantitative Evaluation. Departement of Poultry Science, Mississipi State University. 79 : 391-395.

Redmond, S. B, P. Chuammitri, C. B. Andreasen, D. Palić dan Lamont SJ, 2011. Genetic control of chicken heterophil function in 
advanced intercross lines: associations with novel and with known Salmonella resistance loci and a likely mechanism for cell death in extracellular trap production. Immunogenetics. 63: 449-458.

Salasia, S. I. O dan B. Hariono. 2010. Patologi klinik veteriner. Samudra Biru.Yogyakarta.

Schmidt, C., M. Gocalves, L. Prietto, S. Hackbart dan E. B. Furlong. 2014. Antioxidant activity and enzyme inhibition of phenolic acids from fermented rice bran with fungus Rhizopus oryzae. J. Food Chemistry. 146 : 371-377.

Siegel, H. S.1995. Stress, strain and resistence. Brit. Poultry Sci 36: 3-22.

Siswohardjono, W. 1982. Beberapa metode pengukuran energi metabolisme bahan makanan ternak pada itik. Makalah Seminar Pascasarjana. Institut Pertanian Bogor. Bogor.

Smith, J. B dan S. Mangkoewidjojo. 1988. Pemeliharaan, pembiakan dan penggunaan hewan percobaan di daerah tropis. Universitas Indonesia. Jakarta.

Soeharsono, L. Adriani, E. Hernawan, K. A. Kamil dan A. Mushawwir. 2010. Fisiologi ternak fenomena dan nomena dasar, fungsi dan interaksi organ pada hewan. Widya Padjajaran, Bandung.
Sugiharto, S. 2014. Role of nutraceuticals in gut health and growth performance of poultry. J. Saudi Soc. Agric. Sci. Hal: 113.

Sugiharto, S., T. Yudiarti and I. Isroli. 2015. Functional properties of filamentous fungi isolated from the Indonesian fermented dried cassava with particular application on poultry. J.Mycobiology. 43 (4): 415-422.

Sugiharto, S., T. Yudiarti and I. Isroli. 2016. Assay of antioxidant potential of two filamentous fungi isolated from the Indonesian fermented dried cassava. Antioxidant. https://www.researchgate.net/p ublication. (Februari 2016).

Swenson, M. J. 1984. Physiological properties and cellular and chemical constituents of blood. In Swenson, M. J. Duke's Physiology of domestic animal. Edisi Kesepuluh. Cornell UniversityPress, Ithaca and London.

Widhyari, S. D., W. Ietje, S. Harry dan W. Wiwin. 2009. Efektivitas pemberian kombinasi mineral zinc dan herbal sebagai imunomodulator. J. Ilmu Pertanian Indonesia. 14 (1): 3040. 